Bulletin of the Natural History Museum, 2016, 9: 7-28.

Received 13 May 2015; Accepted 15 Sep 2015.

doi:10.5937/hnhmb1609007M

UDC: 563/565(497.11); 069.51:563/565(497.11)

Original scientific paper

\title{
COLLECTIONS OF PALEOZOIC AND MESOZOIC INVERTEBRATES OF THE NATURAL HISTORY MUSEUM IN BELGRADE - BACKGROUND, CURRENT STATE AND OUTLOOK
}

\author{
ALEKSANDRA MARAN STEVANOVIĆ, RANKO PEJOVIĆ \\ Natural History Museum, Njegoševa 51, 11000 Belgrade, Serbia \\ e-mails: amaran@nhmbeo.rs; pejovic.ranko@nhmbeo.rs
}

Paleontological collections constitute a large part of all natural history collections in Serbia. The main management aim for any significant paleontological specimens is to provide an adequate storage place for such material, to ensure their proper curation and documentation as well as their accessibility and long-term security.

The Natural History Museum in Belgrade is the only institution in Serbia dedicated to collection, protection, preservation and exhibition of moveable cultural property of natural history. Collections of Paleozoic and Mesozoic Invertebrates contain fossils from the territory of Serbia, former Yugoslav republics and other parts of the world. They have been established as the result of lengthy paleontological investigations and museological works. The initial part of both collections was bestowed by the Jestastvenički Cabinet of the Great School in 1901.

Current state of the Paleozoic and Mesozoic Invertebrates Collections is determined based on the appropriate reference parameters, including the access to 
collections and specimens, accessibility of collections and specimens, the type and number of specimens, the purpose and frequency of use, conditions required for storage (security against theft, protection against moisture, flood, fire), utilization of storage space (organisation and functionality), availability of human resources and technical and technological capacities.

Key words: Paleozoic and Mesozoic Invertebrates Collections, Natural History Museum in Belgrade, background, current state, perspective.

\section{INTRODUCTION}

The main purposes of museums as protective institutions are: collection, expert and technical processing, storage and exhibition of moveable cultural property. If museums are to meet these fundamental tasks, in addition to appropriate buildings, showrooms and depots it is essential that they possess necessary expert and technical resources, and that their activities are recognized and acknowledged by both the relevant state institutions and the general public.

Most museums in Serbia operate in buildings that were not built solely for the purpose of storing and displaying museum objects. In this respect, the Natural History Museum in Belgrade shares the fate of the majority of such institutions. However, there are several aspects that make this Museum different from others: even though 120 years have passed since its founding, it is still housed in a "temporary location"; it has no permanent exhibition and, consequently, it is not able to present the diversity and richness of its collections to the interested public.

The Natural History Museum in Belgrade is the only institution in Serbia specialized for collection, protection, preservation and exhibition of moveable cultural property of natural history. It was established on 19 December 1895 under the name 'Jestastvenički Museum'. During its many decades of existence it had functioned under several different names, in various locations and territorial jurisdictions, and has been the charge of many "guardians", committees and ministries.

At the time of establishment of the Museum, the idea was to construct a new building for the Serbian Royal Academy, the National Library and the Jestastvenički Museum on an assigned plot nearby Delijska Fountain (in Knez Mihailova Street, where the Serbian Academy of Sciences and Arts stands today) (Vasić 2002). As a provisional solution until the completion of the dedicated building, the Museum was temporarily placed in the 
endowment house of Stevča Mihajlović ${ }^{1}$ in Kneza Miloša Street 15 (Fig. 1). During the period 1901-1903, the initial natural science fund was kept at this location, along with the collections of the Ethnographic Department of the National Museum. For the most part, the initial paleontological, petrological, mineralogical, zoological and botanical materials were obtained as gifts from the Jestastvenički Cabinet, the Geological Institute and the Chemistry Laboratory of the Great School, but also from the Mining Department of the Ministry of National Economy, other public institutions, and individual donors.

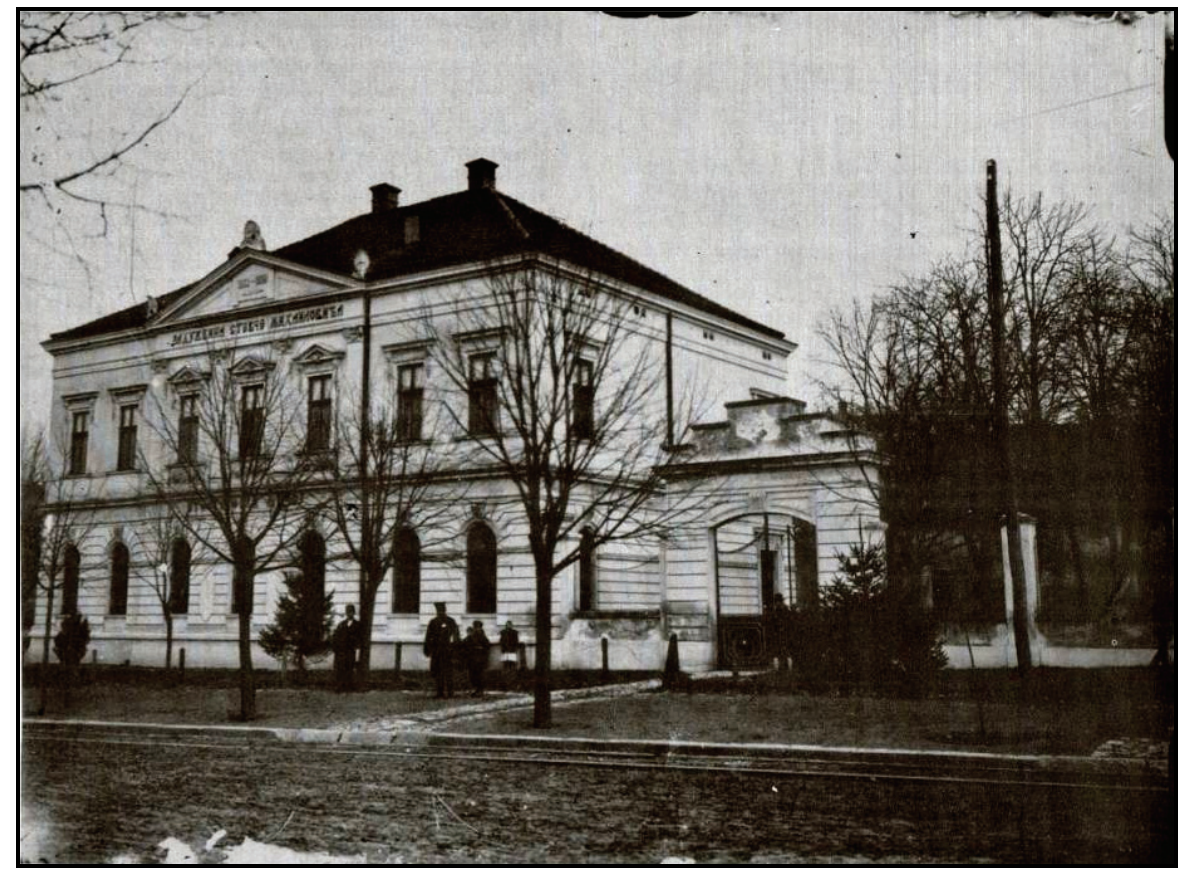

Fig. 1. - The endowment house of Stevča Mihajlović in 1860 (source: V. Andjelković 2009)

Due to the demolition of the endowment of Stevča Mihajlović and the planned construction of a new museum on the same plot, in 1938 the Museum and the Ethnographic Department were assigned two buildings for temporary use: the building of the First Women's High School in Njegoševa Street 51 and the building in the courtyard of Kneginje Zorke Street 56, built to serve as a school (Vasić 2002). Although the endowment of Stevča Mihajlović was indeed demolished, immediately before the outbreak of

\footnotetext{
${ }^{1}$ Stefan Stevča Mihajlović (1806-1888) is one of the most influential Serbian politicians of the 19th century. During the reign of Prince Miloš he served as a Vice-President of St. Andrew's Day Assembly and President of the Ministerial Council of the Principality of Serbia (Stanojlović 2003).
} 
World War II, the idea of providing the Natural History Museum with a new building was never realized. After the liberation, a building that later served other purposes, under different ownership, was erected on the endowment plot. The Ethnographic Museum was assigned the Belgrade Stock Exchange building at the Students' Square, while the Natural History Museum "temporarily" remained where it was: in the premises of the former First Women' High School (Fig. 2).

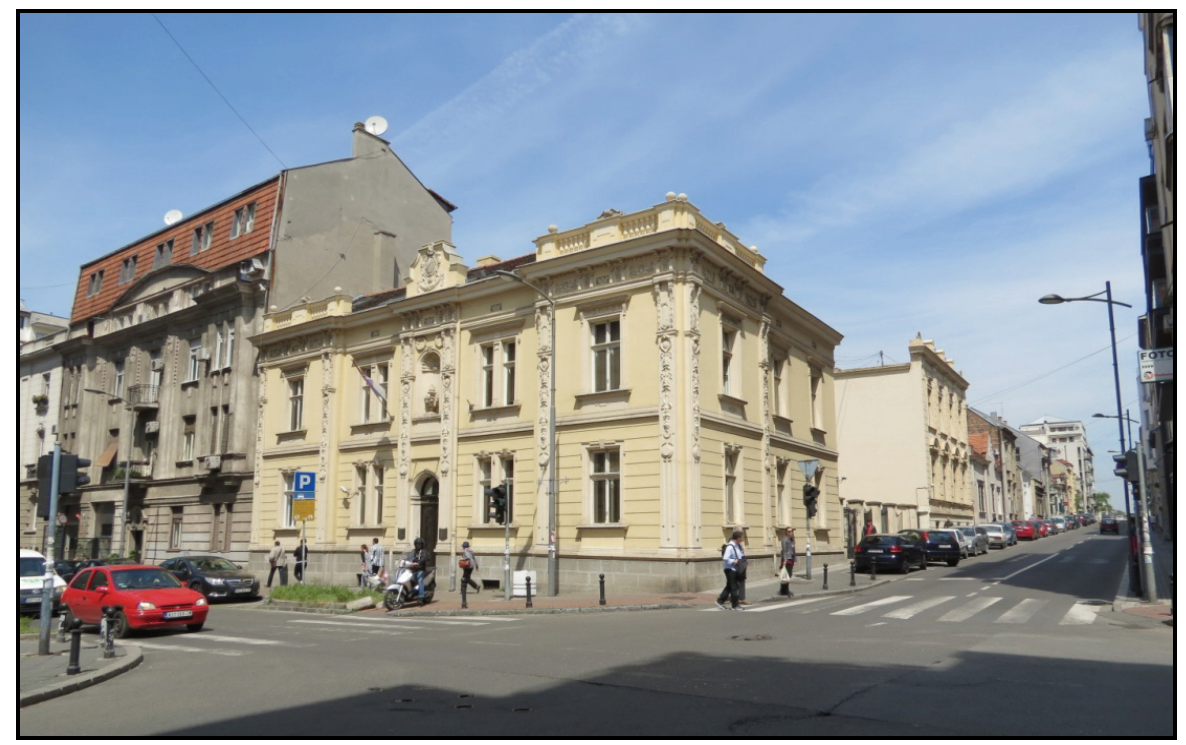

Fig. 2. - Natural History Museum in Belgrade (photo A. Maran Stevanović)

\section{MAIN INFORMATION ON THE COLLECTIONS OF PALEOZOIC AND MESOZOIC INVERTEBRATESOFTHENATURAL HISTORY MUSEUM}

Paleontological collections, estimated to include about 1,000,000 specimens, are divided into 17 thematic sections in line with taxonomy and chronostratigraphy. The scientists and researchers use the collections to answer key questions about the the evolution of life on Earth, ancient environments and past climates, to establish the age of rocks and to correlate rock units in different part of the world. Curators-paleontologists, geological conservator and geological preparator are in charge of their scientific and expert processing, protection and safety.

\section{THE COLLECTION OF PALEOZOIC INVERTEBRATES}

The Collection includes fossils of invertebrates collected in the territory of Serbia and the former Yugoslav republics, the former Soviet Union, 
Great Britain, France, Poland, the Czech Republic and Australia (main information on the Paleozoic Collection, Tab. 1). These animals, of which the majority have no relatives in the modern fauna, lived during the Paleozoic (approximately 542-251 million years ago), one of the longest periods in the geological history of the Earth. The initial part of the collection consists of specimens that had been taken from the Jestastvenički Cabinet of the Great School in 1901. The most numerous fossils are graptolites (Fig. 3). Although there are only a few of them, specimens of trilobites from eastern and western Serbia, as well as those from the Czech Republic, have great scientific and museological significance. Representatives of goniatites (extinct group of cephalopods) of Late Devonian and Early Carboniferous, collected in western Serbia, are holotypes of new species of fossils (Korn \& Sudar 2016). This collection also contains replicas of Ediacara fauna, discovered at the site Ediacara Hills in South Australia, after which this fauna was named. It is a real paleontological curiosity as it includes preserved soft-bodied multicellular organisms, probably animals that only by shape resemble today's jellyfish and sea feathers but have no proper relatives among either extinct or living organisms.

Table 1. - The Paleozoic Invertebrates Collection.

\section{COLLECTION OF PALEOZOIC INVERTEBRATES}

Year of creation

Number of inventory units

Number of inventoried specimens

Number of uninventoried specimens

\section{Collection code}

NHM 600 BEO-551.73:592
1901

1,373

7,166

approximately 5,500 (mostly rock samples with graptolites)

\section{Taxonomic groups of organisms}

Graptolites

Trilobites

Cephalopods (goniatites and nautiloids)

Brachiopods

Bivalves

Gastropods

Echinoderms (starfish) originals (encompassing 90 percent of the entire collection) originals and replicas originals and replicas

originals

originals

originals

originals 
COLLECTION OF PALEOZOIC INVERTEBRATES

\begin{tabular}{ll}
\hline Ediacara fauna & replicas \\
\hline Holotypes & 14 \\
Area & Serbia, Montenegro, Bosnia and \\
& Herzegovina, the territory of \\
& former Soviet republics, Great \\
& Britain, France, Poland, the \\
& Czech Republic, Australia \\
& two authorized curators \\
Professional staff & Curator-adviser, collection \\
& handler (1993-) \\
& Curator (2013-) \\
& performed \\
Categorisation & inventory book, collector book, \\
Documentation & electronic database \\
& formed; inventoried specimens \\
Photo-documentation & have been photographed \\
Storage space & $11.25 \mathrm{~m}^{2}$ \\
\hline
\end{tabular}

Collection code

NHM 600 BEO-551.73:592

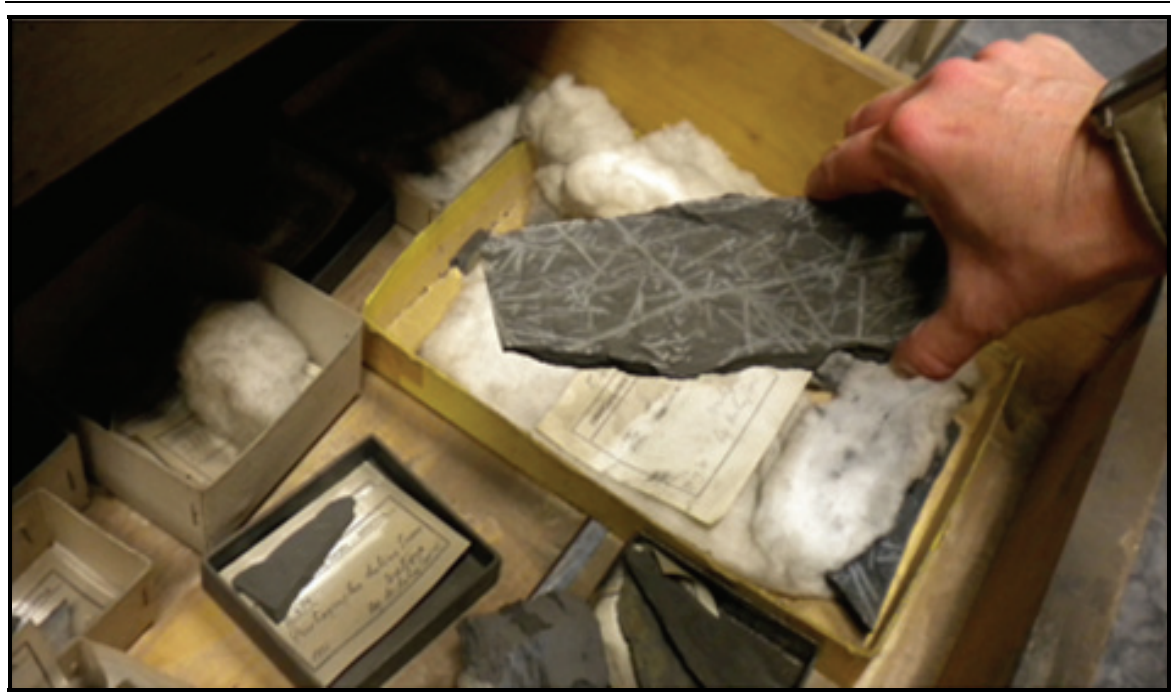

Fig. 3. - Silurian graptolites from the vicinity of Zvonačka banja, eastern Serbia (photo A. Maran Stevanović)

The Paleozoic Invertebrates Collection is kept in a depot located in the basement of the courtyard building (Depot I, Kneginje Zorke St. 56). Until 
1986, the permanent exhibition of the Museum was kept in this $400 \mathrm{~m}^{2}$ space, together with parts of paleontological collections. As the quantity of museum objects was increasing as a result of new acquisitions, a decision was made to disband the permanent exhibition and turn the entire space into a large depot. After the completion of extensive technical works in the main building of the Museum and the reassignment of museum rooms in 2008, the majority of the paleontological collections were moved to a new, refurbished depot (Depot II). Only two rooms within Depot I, with the effective surface area of $85 \mathrm{~m}^{2}$, were assigned to house the paleontological material. The complete Paleozoic Invertebrates Collection was placed in one room, together with a part of the Collection of Large Quaternary Mammals (Fig. 4). The effective surface area of the space that houses the Paleozoic Invertebrates Collection is $11.25 \mathrm{~m}^{2}$.

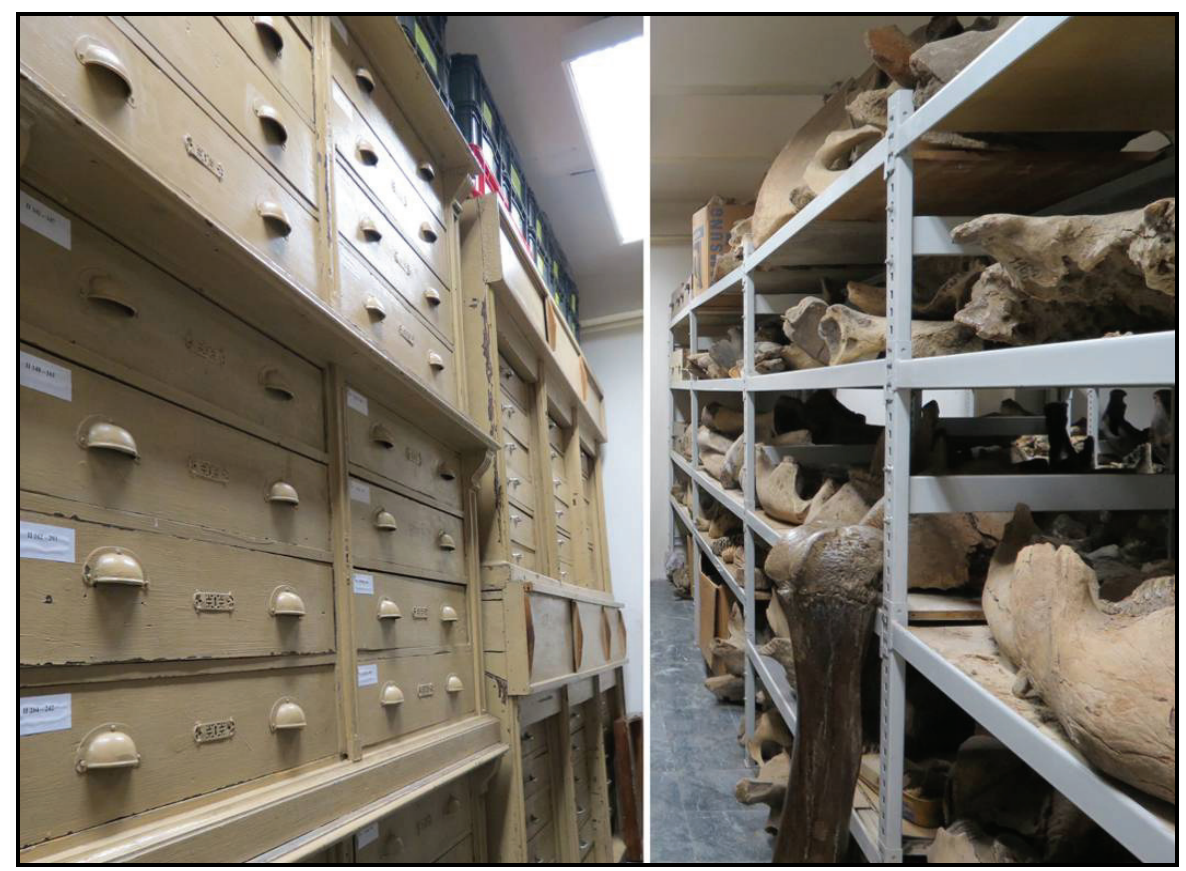

Fig. 4. - The Paleozoic Invertebrates Collection (left), part of the Collection of Large Quaternary Mammals (right), Museum Depot I (photo A. Maran Stevanović)

\section{THE COLLECTION OF MESOZOIC INVERTEBRATES}

The Collection includes fossilized remains of invertebrates that lived in the Mesozoic (approximately 251-65 million years ago), a time period marked by great events and changes in both the appearance of the Earth's 
surface and the composition of the living world. The fossils were collected in the Balkans, Poland, France, Germany, Algeria, Libya and Iraq over a period of more than 100 years. The first specimens in the collection (e.g. brachiopods, gastropods, bivalves and echinoids) were scientifically processed by Dimitrije Antula (1893/1894, part of the initial collection of the Jestastvenički Cabinet of the Great School, Fig. 5) and Petar Pavlović (1909), the first Director of the Museum (main data on the Mesozoic Collection, Tab. 2).

Table 2. - The Mesozoic Invertebrates Collection.

\begin{tabular}{ll}
\hline MESOZOIC INVERTEBRATES & $\begin{array}{l}\text { Collection code } \\
\text { NHM 600 BEO-551.76:592 }\end{array}$ \\
\hline Year of creation & 1901 \\
Number of inventory units & 3,326 \\
Number of inventoried objects & 7,774 \\
Number of uninventoried objects & approximately 3,000 \\
\hline
\end{tabular}

Taxonomic groups of organisms

Foraminifers

originals

Corals

originals

Cephalopods (ammonites, originals and replicas belemnites)

Brachiopods originals

Gastropods originals

Bivalves originals

Echinoderms (sea urchins, sea lilies)

Holotypes originals

Area 31

Serbia, Montenegro, Bosnia and Herzegovina, Poland, Germany, France, Algeria, Libya, Iraq

Professional staff one curator, collection handler

Categorisation performed

Documentation inventory book and collector book; electronic database is currently being created

Photo-documentation formed; inventoried specimens have been photographed

Storage space $30 \mathrm{~m}^{2}$ 


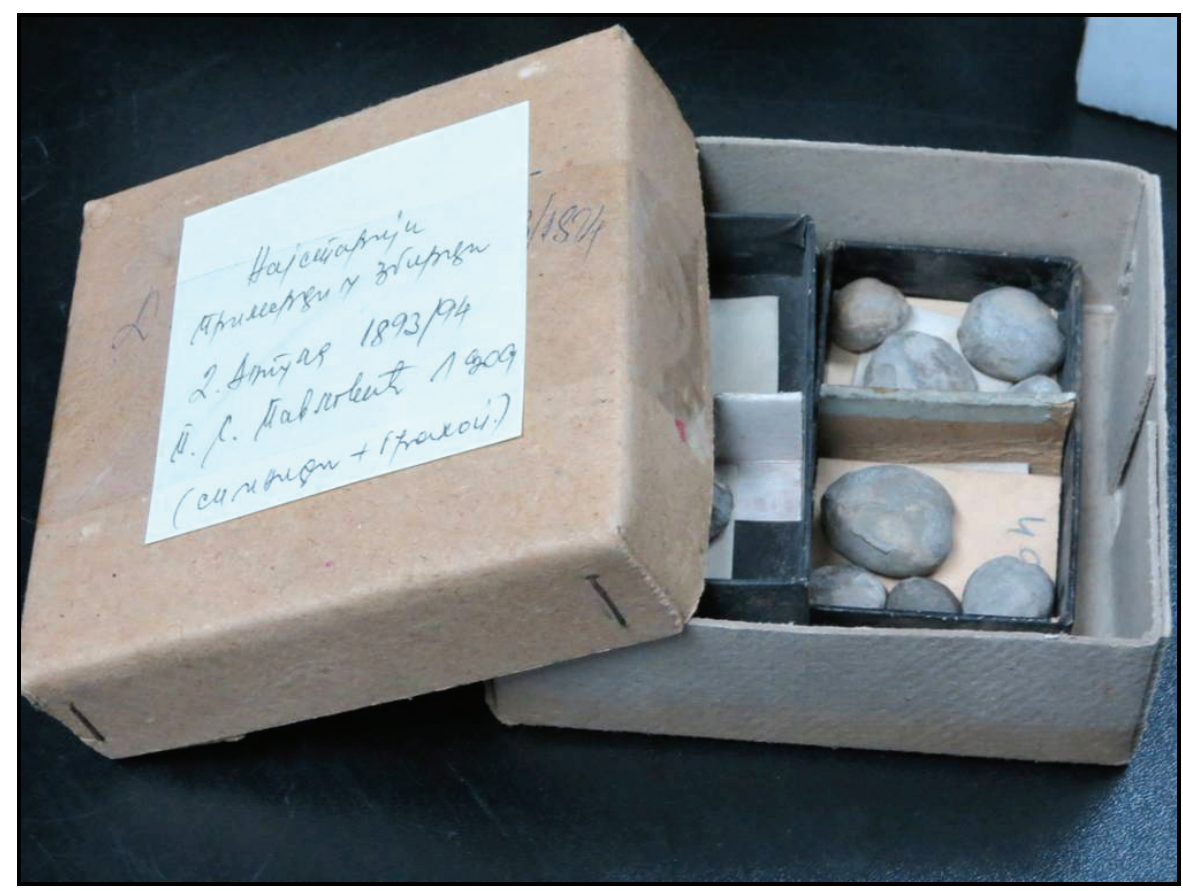

Fig. 5. - Brachiopods and echinoides, collected and scientifically processed by D. Antula (photo A. Maran Stevanović)

Most representatives of the Mesozoic marine animals (e.g. ammonites, belemnites, rudists) do not have relatives in the modern fauna, and their preserved remains are unique and irreplaceable forms testifying on the richness of life at that time. Parts of the Collection, representing reference materials for numerous monographic studies on invertebrates of Serbia and Balkan Peninsula, have special scientific, educational and museological significance. The Jurassic ammonites collected in the Djerdap Gorge, on the Greben ridge (Fig. 6), are not only the most common fossils in the collection but also signify paleontological and museological rarities because they derived from a site that had been partially sunk during the construction of the Djerdap Dam. Specimens of corals discovered in eastern Serbia (Mt. Stara Planina: Žljebine and Planinica, age: Lower Cretaceous) are holotypes of new species of fossils (Turnšek \& Mihajlović 1981).

The Mesozoic Invertebrates Collection is kept in a depot in the basement of the main Museum building (Depot II in Njegoševa St. 51, entrance from the courtyard, Fig. 7) which has a total surface area of 190 $\mathrm{m}^{2}$. The depot consists of two parts. The first, smaller part, houses the General Paleobotanical Collection, while the second, larger part (with a total surface area of $155 \mathrm{~m}^{2}$ ) houses seven collections: 1) the Mesozoic Invertebrates Collection, 2) part of the Cenozoic Invertebrates Collection, 


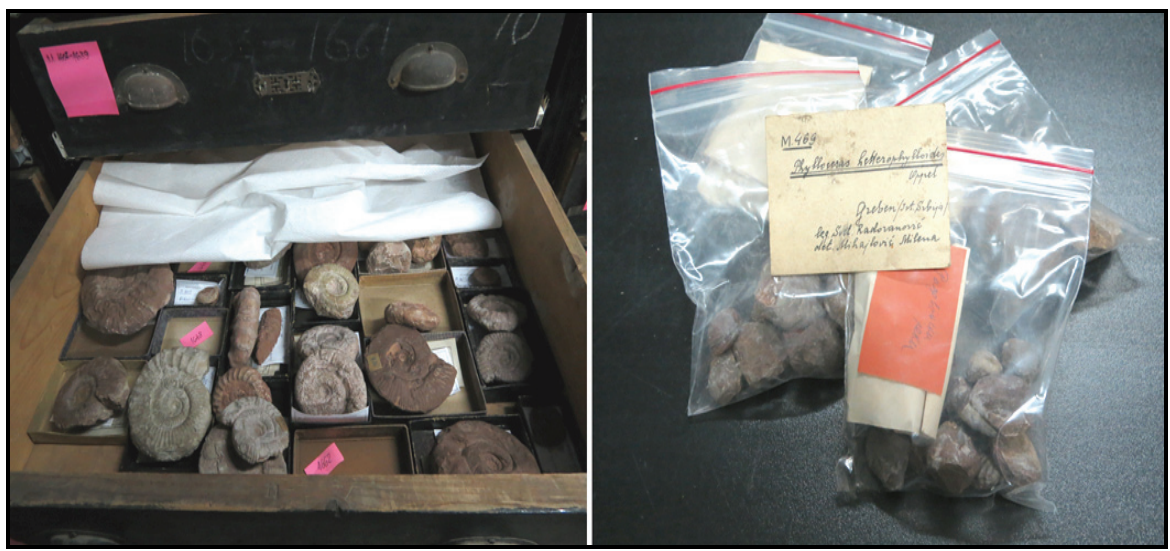

Fig. 6. - Jurassic ammonites from the Greben Ridge (Djerdap Gorge, eastern Serbia (photo A. Maran Stevanović)

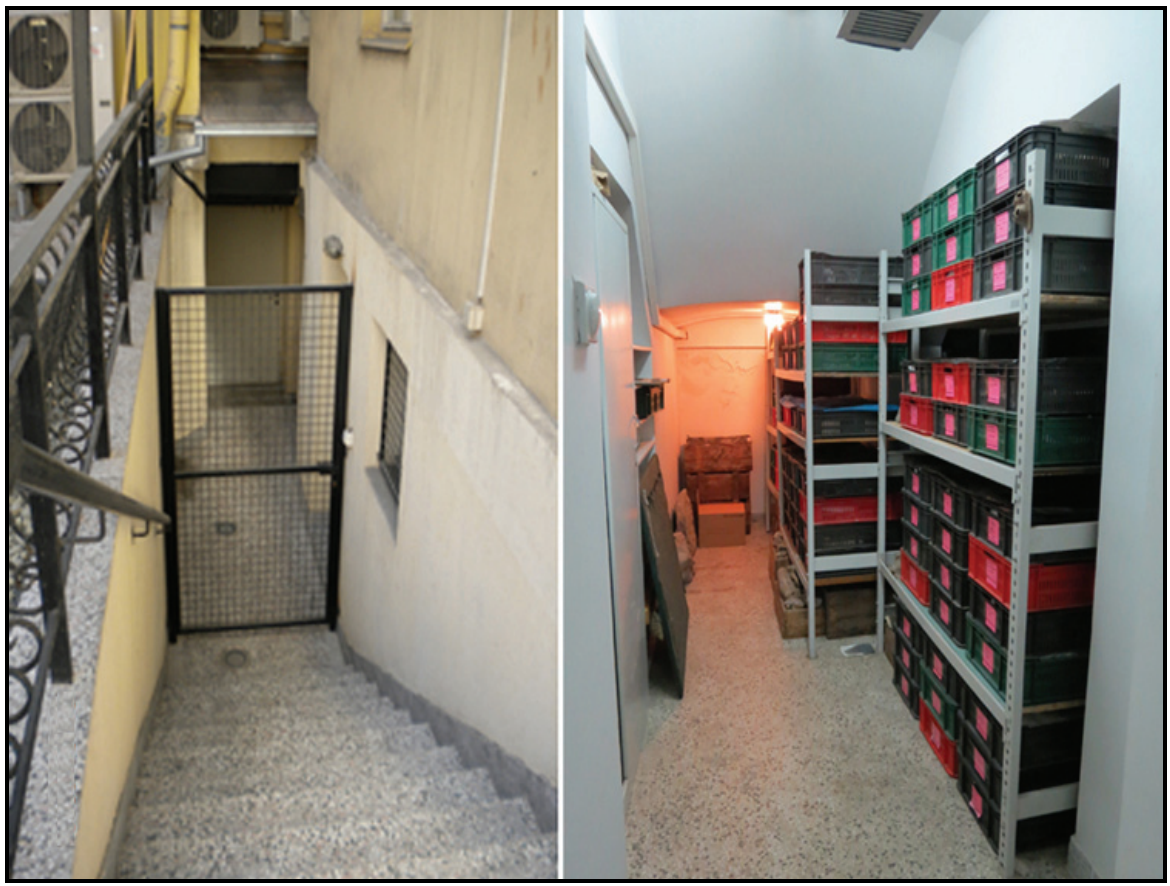

Fig. 7 - Entrance to the Museum Depot II (left); part of the Mesozoic Invertebrates Collection (right) (photo A. Maran Stevanović)

3) the Paleontological Collection of P. Stevanović, 4) the Paleontological Collection of N. Krstić, 5) the Collection of Fish, 6) part of the Collection of Large Tertiary Mammals, 7) part of the Collection of Large Quaternary Mammals, as well as some of the furniture used for visiting geological exhibitions. Inventoried and uninventoried specimens from the Mesozoic 
Invertebrates Collection are housed in two rooms with the effective surface area of $30 \mathrm{~m}^{2}$ (Fig. 8).

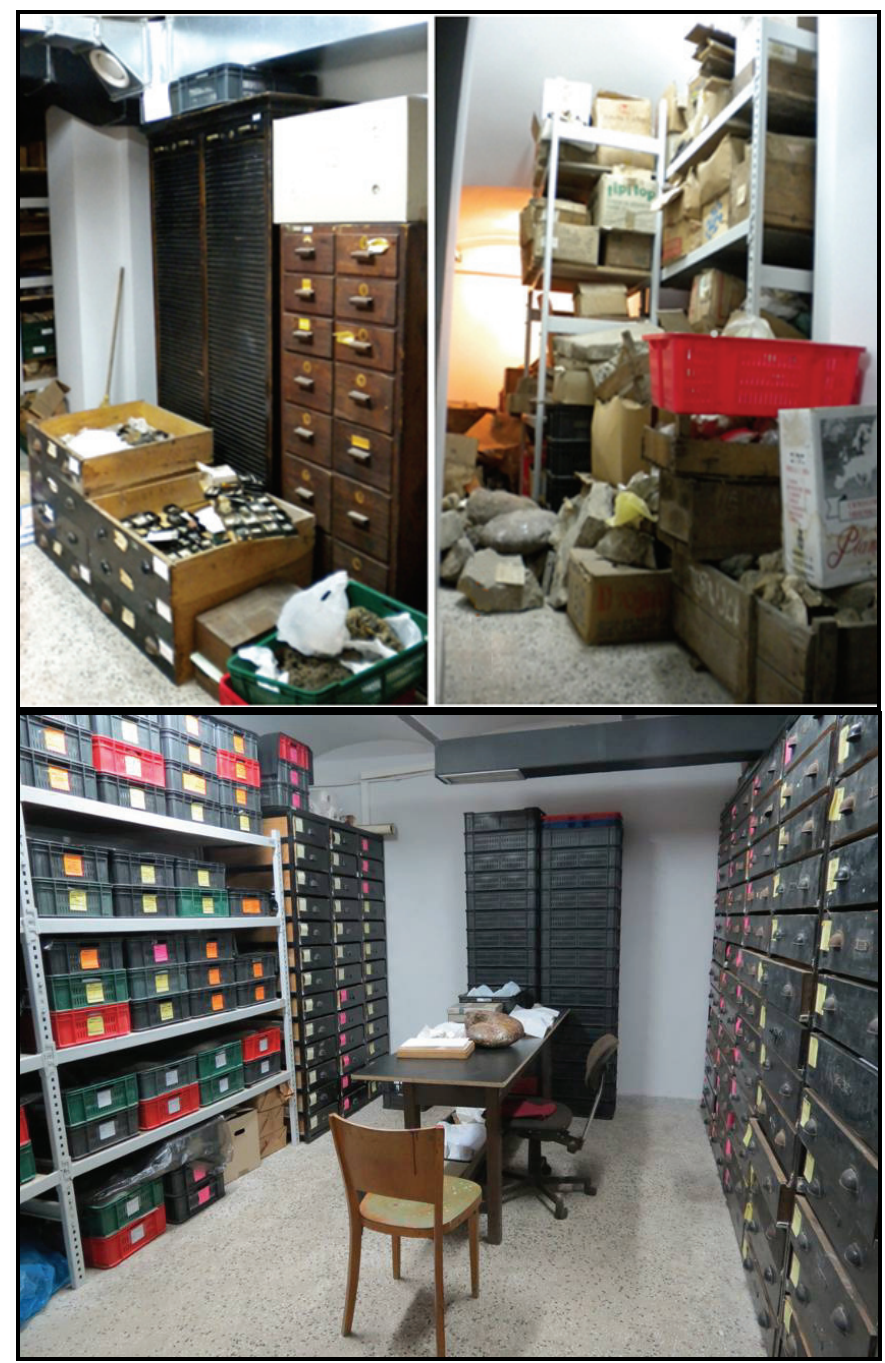

Fig. 8. - Mesozoic Invertebrates Collection before and after arrangement (photo A. Maran Stevanović)

\section{DOCUMENTATION ON PALEONTOLOGICAL COLLECTIONS}

Paleontological collections can be formed gradually by collecting the material during field research, but may also be acquired by exchange or sale, or as legacies. Paleontological material gathered during field work has a long way to go before it can be housed in a collection. The first steps 
toward data collecting are done in the field and comprise all observations on collected material entered in the field book, which is used later for other temporary and permanent documents (Maran 2010). When the field research has been completed, undetermined material is recorded in the collection book. The collection book (or book of incoming material) and collector labels are obligatory documents for temporary usage.

Determined paleontological material is 'permanently' documented. The data are recorded when the material has undergone expert analyses and technical treatment (different preparation and conservation methods). An expert analysis includes complete identification of material, verification and evaluation of all information important for categorization and conservation. Data on identified and technically treated material are archived in the inventory book (register of fossils) as well as in the electronic database.

The contents of the register include: 1) inventory number, 2) scientific name of fossil, 3) place of origin with geographical coordinates, 4) stratigraphic level, 5) date when it was collected, 6) name of person who collected it (or the name of donor), 7) name of the person who identified the fossil(s), and 8) additional notes (Fig. 9). The register should have a hard cover with archival quality paper and it has to be kept in a secure location, as a fire-proof safe. In addition, if possible, the museum should keep also a copy of the register at another location.

The documentation on the paleontological collections (in paper and electronic form) represents their complementary part, and only the proper archiving of data allows the collections to develop their full scientific value and importance. Each institution housing paleontological material ought to have complete documentation, an identification code and collection codes. The Natural History Museum in Belgrade has the code - NHM 600 BEO. Accurate and accessible documentation is an essential resource for collections management and research.

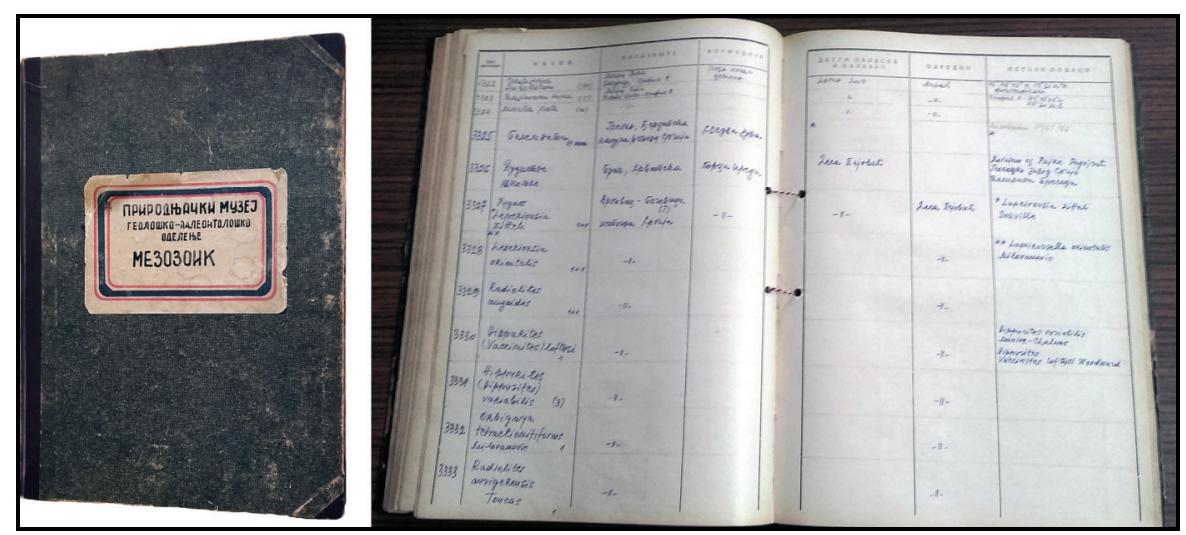

Fig. 9. - Inventory book of the Mesozoic Invertebrates Collection. 


\section{THE COLLECTIONS OF PALEOZOIC AND MESOZOIC INVERTEBRATES - ASSESSMENT OF CURRENT STATE}

In order to achieve optimal conditions for the preservation and use of paleontological collections, it is necessary to consider all the relevant factors of their external and internal environments (Maran Stevanović et al. 2016). External risks are objective factors from the external environment that generally cannot be influenced (existing political, social or economic environments, unpredictable natural processes). Internal factors (internal environment) are the potentials or limitations within the institution in which the items and collections are kept, and they include the presence or absence of appropriate organizational structure, professional staff, financial resources, program activities (scientific, expert, educational) and information technologies. According to Waller \& Shelton (1989), Baer (1991, 2001), Roberts (1993), Michalski (2004) and Muething et al. (2005), the most common causes of deterioration (degradation) of museum items are:

* Physical forces (earthquakes, building collapse, items falling down and being damaged as a result);

* Natural disasters (fire, floods, landslides);

* Light and ultraviolet radiation;

* Humidity;

* Pests and microorganisms;

* Theft and vandalism;

* Incompetent or negligent handling of items.

The state of the paleontological specimens and collections is determined based on the appropriate reference parameters (Tab. 3):

* Access to collections and items;

* Accessibility of collections and items;

* The type and number of items;

* The purpose and frequency of use;

* Conditions required for storage (security against theft, protection against moisture, flood, fire)

* Organisation, functionality and utilization of storage space;

* Availability of human resources;

* Technical and technological capacities.

The long-term policy for the protection of the paleontological collections is thought-out and planned based on the analysis of the state of the spe- 
cimens (objects or items) and collections (Tabs 4-5), the identified risk factors, and the monitoring of the frequency of their occurrence.

Table 3. - Reference parameters.

\section{REFERENCE SYSTEM INDICATORS}

\section{NATURAL HISTORY \\ MUSEUM \\ Paleozoic Invertebrates \\ Collection}

Mesozoic Invertebrates

Collection
Human resources

Technical capacity

The state of specimens and collections

Purpose and frequency of use of specimens and collections

Organisation and functionality of Access and entrance to the building the space

Access and entrance to the depot

Utilization of space in the depot

Connection of the depot to the curators' workspace

Access to collections

Storage of collections

Storage of specimens

Accessibility of collections

Accessibility of specimens

Time required to locate an object

Protection of collections

Theft/Protection from theft

Water/Protection from flooding

Fire/Protection from fire

Climatic conditions

Light sources

Pests and microorganisms

Cleaning of objects and furniture 
Table 4. - The Paleozoic Invertebrates Collection - assessment of current state.

Storage space:

Museum depot I
Professional staff:

Two curators, one collection handler

* Preparation and conservation tasks are performed by curators

Technical capacity:

Below minimum: central neon lighting and a ventilation system.

There is no device to measure relative humidity.

Condition of specimens and collections:

Surface area of the space: $11.25 \mathrm{~m}^{2}$

Number of objects: approximately 12,500

Specimens are mostly of smaller in size, neatly put away, clearly and visibly labeled, arranged by inventory number, protected from dust.

Frequency and purpose of use:

Occasionally used for exhibitions (thematic exhibitions) and educational purposes.
Organisation and functionality of space
Access to the building and depot: accessible.

Access to the collection: partially accessible.

The area is congested, dysfunctional when work is required; handling of objects is somewhat difficult.

The space is maximally organized, in relation to the surface area and the number of objects kept in it.

The curators' offices are far, the transfer of objects from the depot to the curators' workspace is complicated. 
Access to collection
Who can access the collection: curators.

Collection is stored in: dilapidated wooden cabinets without a sliding mechanism, plastic crates.

Inventoried objects are stored in: clearly labeled cardboard boxes and plastic bags, placed in wooden cabinets.

Uninventoried objects are stored in: plastic crates, with clearly visible collector labels.

The collection is partially accessible, the space is overcrowded.

Inventoried objects: accessible, clearly labelled, easy to find.

Uninventoried objects: difficult access (crates are stacked one on top of the other, placed on top of the cabinet).

Protection of the collection

The collection and specimens are safe from theft: metal fences have been erected at the entrance to the depot and at the entrance to the collection; when not used, the collection is locked.

The collection and objects cannot be protected from flooding (basement space).

The collection and objects are protected against fire: a fire hydrant and fire extinguishers have been installed and their proper working order is controlled.

Light sources: fluorescent lighting; natural lighting is not used (the existing windows are covered).

Pests and microorganisms: fumigation and pest control are regularly carried out. 
Cleaning of objects and furniture: is performed periodically; objects are protected by thin packing paper and nylon. The condition of objects and the collection is controlled three times per week.

The space is regularly cleaned and maintained.

Table 5. - The Mesozoic Invertebrates Collection - assessment of current state.

Storage space:

Museum depot II
Professional staff:

One curator, collection handler

* Preparation, conservation and technical tasks are performed by the curator

Technical capacity:

Relatively good: central fluorescent lighting; a ventilation system and a system to regulate temperature and humidity have been installed.

There are no heaters.

There is no natural light source.

Equipment required for work has been provided (binocular magnifier, magnifying loupes, scientific and technical literature).

Condition of specimens and collection:

Surface area of the space: $30 \mathrm{~m}^{2}$

Number of objects: approximately 11,000

Objects are neatly put away, clearly and visibly labelled, arranged by inventory number, protected from dust.

Frequency and purpose of use:

Objects from the collection are relatively often used for scientific and technical research, education, student practice and exhibition purposes (thematic exhibitions). 
Organisation and functionality of space
Access to the building and depot: accessible.

Access to the collection: accessible.

The area has been cleared out, is functional for work and the handling of objects; the space is maximally organized, in relation to the surface area and the number of objects kept in it. The curator's office is far (courtyard building). It is complicated to bring objects in and take them out. The weight of most objects exceeds $30 \mathrm{~kg}$.

Access to the collection

Who can access the collection: authorized curator, collection handler. The collection is stored in: a metal cabinet, wooden cabinets with a sliding mechanism with wheels, open metal shelves.

Holotypes and rare and fragile fossils are stored in: a metal cabinet.

Inventoried objects are stored in: wooden and cardboard boxes, plastic bags, metal shelves (storage of massive and heavy objects, and often exhibited objects/visiting exhibitions).

Uninventoried objects are stored in: plastic crates, plastic and cotton bags (sensitive materials); heavy and massive objects are placed directly on shelves.

The collection is accessible; the space has been cleared out.

Manipulation of massive and heavy objects is complicated.

Inventoried objects: accessible, clearly labeled, easy to find.

Uninventoried objects: difficult to access (crates are stacked one on top of the other). 
Protection of the collection
The collection and objects are protected from theft: the metal door is locked; access to the collection is controlled (accessible only to the authorized curator, collection handler). The collection and objects cannot be protected from flooding (basement space).

The central air conditioning system and a device that measures and controls relative humidity have been installed. The collection and objects are protected from fire: a fire hydrant and fire extinguishers have been installed, and their proper working order is controlled.

Light sources: fluorescent lighting; there is no natural light source.

Fumigation and pest control are regularly carried out.

Objects are protected by paper towels; crates are covered by nylon.

The condition of objects and the collection is controlled three times per week.

The space is regularly cleaned and maintained.

\section{CONCLUDING REMARKS}

The Paleozoic and Mesozoic Invertebrates Collections are stored in three rooms located in separate depots; their effective surface area is 41.25 $\mathrm{m}^{2}$. They are kept in inadequate technological conditions, but are protected from decay and destruction.

The number of specimens in these collections has been estimated at 23,000; however, 8,500 of the total number of specimens have yet to be inventoried. Uninventoried material includes the Silurian graptolites from eastern Serbia (the Paleozoic Collection), the Triassic ammonites originating from sites in western Serbia (the Mesozoic Collection), and the Jurassic ammonites collected at localities along the Djerdap Gorge (the 
Mesozoic Collection). Until 1993, the collections were handled by a single curator who was a specialist in graptolites and ammonites, and it is therefore not surprising that precisely these specimens dominate in the collections. In the period 1993-2013, the scientific and expert processing of specimens was also performed by a single curator, the collections handler. In 2013, an additional curator was engaged to work on the Paleozoic collection. In terms of human resources, the optimal working conditions would require four people: two curators (one curator per collection), one preparator/conservator, and one technician.

The specimens in the collections vary in size and weight, from small fossilized remains (e.g. microscopically small forams and coral thin sections) to extremely massive and large (coquinas, specimens of ammonites and rudist shells weighing more than 30 kilograms). In addition to requiring good physical fitness and strength, handling heavy specimens can also be dangerous for a curator.

Dilapidated wooden drawers are used for the storage of inventoried specimens of smaller size, while massive specimens are placed on metal shelves. Uninventoried material is generally stored in plastic crates, which are stacked on top of each other as a result of insufficient space.

Inventoried specimens of fossils are categorized according to their importance and value. Scientific revision is conducted periodically, in line with new scientific discoveries. Type material (holotypes and specimens of exceptional scientific and museological significance) is kept in the manner prescribed.

Access to buildings and depots is controlled by security personnel. Cameras and monitors have been placed in the appropriate strategic locations inside and outside the museum buildings. Collections are protected against theft and fire. The proper working order of fire extinguishers and hydrants is controlled in accordance with statutory regulations. Collections are protected from various pests by regular fumigation and pest elimination. Since the depots are located in the basement, penetration of water in case of flooding cannot be prevented, with the exception of preventive evacuation of objects. Improper handling is kept to a minimum, as only authorized curators have access to the collections.

The collections are missing specimens of fossils that cannot be found in Serbia. There are a few options for their procurement (e.g. purchase from private collectors, at mineral and fossil fairs, or from Internet on-line shops), but there is a problem of lack of funds. Field research, although it represents the main form of acquisition of materials for collections, has been limited for the same reason. Specimens are collected mainly in line with the professional orientation of the curator, not reflecting real needs. 
The optimal organisation and functionality of depots used for storage of collections has been achieved, and no further adaptations of the existing space in the Museum are possible. What is needed is a new building, constructed specifically to host the Museum.

\section{REFERENCES:}

Baer, S. N. (1991): Assessment and management of risks to cultural property. In: Baer, S. N., Sabbioni, C., Sors, A. I. (eds): Science, technology, and European cultural heritage. Proceedings of the European symposium, Bologna, Italy, 1316 June 1989: 27-36. - Butterworth-Heinemann, Oxford.

Baer, S. N. (2001): Risk management, value and decision-making. - The Paper Conservator 25(1): 53-58.

Korn, D., Sudar, M. (2016): The Late Devonian and Early Carboniferous ammonoids (Cephalopoda) from Milivojevića Kamenjar, Družetić (NW Serbia) and their stratigraphy. - Bulletin of Geosciences 91(1): 187-210. (32 figures, appendix)

Maran, A. (2010): Valuing the geological heritage of Serbia. - Bulletin of the Natural History Museum in Belgrade 3: 47-66.

Maran Stevanović, A., Ganić, M., Rundić, Lj., Milovanović, D. (2016): Upravljanje rizicima u zaštiti objekata geonasleđa Srbije/Risk management in the area of geoconservation of the Serbia's geoheritage. - Jubilarna sveska, Zapisnici Srpskog geološkog društva za 2016. godinu: 111-136. [In Serbian]

Michalski, S. (2004): Care and preservation of collection. - In: Boylan, P. (ed.): Running a Museum. A Practical Handbook: 51-89. - International Council of Museums \& UNESCO, Paris.

Muething, G., Waller, R., Graham, F. (2005): Risk Assesment of Collections in Exhibitions at the Canadian Museum of Nature. - Journal of the American Institute for Conservation 44(3): 233-243.

Roberts, B. O. (1993): Establishing a disaster prevention/response plan, an international perspective and assessment. - Technology and Conservation 4: 15-36

Stanojlović, N. (2003): Testament of Stefan-Stevča Mihajlović. - Koreni 1: 155168. [In Serbian]

Turnšek, D., Mihajlović, M. (1981): Lower Cretaceous Cnidarians from Eastern Serbia. - Razprave, Slovenska akademija znanosti in umetnosti, Razred za prirodoslovne in medicinske vede 23(1): 1-54. (50 plates)

Vasić, V. (2002): Basic information about the Natural History Museum in Belgrade. - Archive of the Natural History Museum in Belgrade / Arhiva Prirodnjačkog muzeja u Beogradu. - Natural History Museum, Belgrade. (manuscr.) [In Serbian]

Waller, R., Shelton, S. (1989): Risk management strategies applied to the development of pragmatic solutions to collections storage problems. In: Anonymous $(e d$.$) : "The Society for the Preservation of Natural History Collections".$ 
Fourth Annual Meeting, July 23-28, 1989. Programme and Abstracts: 32. Turrel Museum of Paleontology Drumheller, Biological Sciences Department University of Calgary, Calgary.

\title{
ЗБИРКЕ ПАЛЕОЗОЈСКИХ И МЕЗОЗОЈСКИХ ИНВЕРТЕБРАТА ПРИРОДЊАЧКОГ МУЗЕЈА У БЕОГРАДУ - ИСТОРИЈАТ, АКТУЕЛНО СТАЊЕ И ПЕРСПЕКТИВА
}

\author{
АЛЕКСАНДРА МАРАН СТЕВАНОВИЋ, РАНКО ПЕЈОВИЋ
}

\author{
Р Е 3 И М Е
}

Природњачки музеј у Београду, основан 1895. године, једина је институција у Србији специјализована за прикупљање, заштиту, чување и излагање покретних природњачких културних добара.

Палеонтолошке збирке Музеја, чији се укупан фонд процењује на око 1.000.000 примерака, обухватају 17 тематских целина. За њихову научну и стручну обраду, заштиту и безбедност одговорни су надлежни кустоси, геолошки конзерватор и геолошки препаратор.

Збирке палеозојских и мезозојских инвертебрата обухватају примерке разноврсних фосила сакупљене на територији Србије, бивших југословенских република, Балканског полуострва као и других делова света. Њихов иницијални фонд чине примерци преузети из Јестаственичког кабинета Велике школе 1901. године.

Стање збирки палеозојских и мезозојских бескичмењака анализирано је на основу одговарајућих референтних параметара, укључујући приступ збиркама и примерцима, доступност збирки и примерака, врсту и број примерака, циљ и учесталост њихове употребе, услове складишног простора (организација, функционалност, сигурност од крађе, заштита од влаге, поплаве, пожара), покривеност људским ресурсима и техничко-технолошке капацитете.

Као део закључног разматрања издвојена је чињеница да, иако је постигнута оптимална организација и функционалност депоа у којима се чувају палеонтолошке збирке, у Музеју више не постоји могућност за било какве додатне адаптације. Перспектива је нова зграда, која би се наменски градила за Природњачки музеј. 